\title{
Russian Export Strategy and Social Sector: Consequences of Resource-Oriented Exports on Population of Russia
}

\author{
N. Didenkoa \\ K. Kunze \\ D. Skripnukc \\ a Professor, Department of International and Regional Economics, Peter the Great St. Petersburg Polytechnic University \\ Polytechnicheskaya Street 29, 195251 St. Petersburg, Russia.Email: didenko.nikolay@mail.ru \\ b Graduate Student, Department of Economics, University of Colorado, Denver, 1380 Lawrence Street \\ Denver, C0 80204, Email: konstantin.kunze@ucdenver.edu \\ c Professor, Department of International and Regional Economics, Peter the Great St. Petersburg Polytechnic University \\ Polytechnicheskaya Street 29, 195251 St.Petersburg, Russia.Email: djamilyas@mail.ru
}

\section{Doi:10.5901/mjss.2015.v6n5s2p473}

\section{Abstract}

This paper presents the analysis of the Russian resource-oriented export strategy. Focusing on the consequences on the population of Russia the relationship between the export strategy of Russia and the social sector is examined. Based on data between 1990 and 2012 the causal relationship between the Russian production and export of oil, price of oil at the world market, and dynamics of the social sector, including the GINI index, average wage, savings of the households, and the development of fuel and energy complex is analyzed. The results show that the export of raw materials can significantly improve the development of the Russian social sector under the condition of growing demand for the energy resources. The results suggest that the country with vast oil and gas reserves should target the policy of restricting the exports and stimulating its consumption within the economy.

Keywords: exporting strategy of raw materials, Gini coefficient, average wage level, household savings, Russian oil production, Russian oil exports, oil price.

\section{Introduction}

The modern development of the Russian economy is closely linked to the strategy of the export of raw materials. This export orientation has lead generally to positive consequences for Russian economy. What are these positive results? They can be evaluated with the economic growth indicator. The indicator was at a pretty high level because of the development of the fuel and energy sector. It is primarily oil and gas industry that is connected with production, processing and exporting of oil and gas resources. It is also connected with consumption of the resources.

The theoretical grounds of the raw materials oriented exporting strategy are based on the research of the natural resources and its impact on the socio-economic development of the country performed by W.Petty, A.Smith, T.Malthus, D.Ricardo, J.B.Say, C.Marx, J.Schumpeter et al.

The methodological success of the resource-oriented exporting strategy is based on the theories of the absolute and comparative advantages, on the theory of M.Porter, on the theory of economic development and the so called Dutch disease concept. Corden (1984), Hutchison (1994), Edwards and Aoki (1983), Didenko (2007), Didenko and Skripnuk (2014)

In the recent economic literature Gouriev and Sonin (2008) and Kimelman and Andriushin (2007) describe the "Russian Disease" with features such as raw materials export specialization and massive exporting of capital (primarily caused by exports of raw materials). Some of the studies discuss the problems of industrial potential of both companies and the whole economic sectors and the interdependence of exports and the economic growth of the country. Balassa (1978), Giles and Williams (2000a), Giles and Williams (2000b) Lederman et. al. (2010), Lederman et. al. (2007), Leonidou (1995), Martincus (2010)

The purpose of this article is to study the possibilities of resource-oriented export strategy of Russia. The effectiveness of the resource-oriented export strategy was evaluated based on the following social sphere indicators: 
GINI index, average wage, savings of the households, and the development of fuel and energy complex. In line with this objective the following problems were solved: finding the functional dependence of each of these indicators of social sphere with the extraction of oil, export of oil, and price of oil.

This research is mainly focused on the industrial potential of various economic sectors, including the sectors of raw materials, on the sectorial distribution of GDP, on the interdependence of the resource sectors and the economic growth. The $2 \mathrm{D}$ production possibilities curve that shows the industrial potential for two sectors of national economics within the resource-oriented strategy implies the redistribution of resources to the sector of raw materials. The above-mentioned research shows that the process of resource redistribution implies industrial growth in the raw materials sector at the expense of other segments. But viewed as a whole, it might lead to overall economic growth. The rise in industrial possibilities of the resource sector entails lower demand in other sectors. Russia is the second largest natural gas producer and the third largest oil producer in the world. The oil and gas receipts constitute approximately $52 \%$ of the federal budget and are about 70\% of the Russian exports (according to 2012 statistics of PFC Energy) EIA (2015). Whereas the resource-oriented export strategy is being implemented in its most inertial variant. The country simply produces the energy resources and exports them.

As it was already mentioned above, the resource-oriented export strategy provides for Russian economic growth, but what does actually happen in the social sector is ambiguous. This question is not well analyzed in the modern research. How does the resource-oriented export strategy influence the human being? The answers to these questions can be evaluated with the above-mentioned strategy and characterize it as successful or not.

The Russian economy has been showing relatively high growth figures for a long period of time. But once there was a moment where the system came to stall, the growth indicators moved in downtrend. It might be that the world crisis is here to blame, but it might be also that the resource-oriented export strategy has a negative effect. This is to be found out whereas neither the gas, nor oil prices are falling. Of course, some prices on the exported materials have fallen, but these prices are always fluctuating, but for the major export items - oil and gas - the prices are stable. What made the Russian economy to slow down?

We can make an assumption that the resource-oriented export concept has become anachronistic and it probably should be replaced.

It should be pointed out that some analysts, researchers and practitioners are of the opinion that this resourceoriented concept is to be replaced. But what concept should replace the existing one: the innovative development strategy for the economy, or semi-innovative strategy, or innovative strategy for the sector of raw materials? There are many different points of view. The main idea is to decide whether the existing export strategy is obsolete or not. The idea is to get the answer about the validity of the existing export strategy with the help of our newly developed methodological approach.

\section{Description of Methodology}

The influence of the resource-oriented export strategy that provides for economic growth on the social sector and the human being is the core idea of the methodological analysis. How can we examine this influence?

There are several steps to be taken. The first step is the analysis of the fuel and energy sector with the stress on major development factors. Within the fuel and energy sector one should analyze the role of the oil sector, as the main element of the fuel and energy sector. Then the social sphere of the Russian economy should be taken into consideration. Here principles and indicators of the analysis are to be justified. The next step is to show on substantial and formal levels the ways of interdependence of the fuel and energy sector with the social sphere.

The fuel and energy sector is the most important element of the Russian economics. It is one of the key factors of functioning of the economic system. More than a quarter of the whole industrial production in Russia falls on the fuel and energy sector. It also plays a decisive role in the federal budget receipts.

The sector is vast. In the methodology we shall take only the oil segment. This choice is stipulated by the following circumstances.

Firstly, while analyzing the oil sector, we can combine not only oil production (domestic consumption) and export, but also the oil price, which is very important for us. The oil sector has very tight system of interdependencies. We shall analyze the performance of the sector. Moreover, the oil sector is the major element of the fuel and energy sector when viewed from the absolute production indicators.

The most crucial factor is whether the resource-oriented export strategy is still valid or not. One can consider the export strategy as no longer valid because of decreasing growth indicators of the Russian economy. Although the economic growth is a very important factor, the priority in this study lies on the social sector, in other words, whether the 
existing Russian export strategy is socially justified and still valid or not?

To answer this question various social indicators have been considered for the analysis. The group of social indicators can be represented with the indicators of welfare assistance and social support, education, health care, housing standards, utilities, transport and communications, culture, crime situation and others. To the moment various standard indices that consider qualitative parameters of human development are implemented. Most commonly accepted is the Human Development Index (HDI), which was introduced in the Report about human development in 1990. Some researchers point out, that $\mathrm{HDI}$ is less effective for domestic analysis then for international comparisons. That can be explained with GDP per capita that plays a decisive role in the HDI index. From the variety of social principles and indicators we have selected the following: the social justice principle, the average wage level in the country and the household savings.

The principle of social justice is selected because justice is one of the basic concepts of social development. If people feel justice in the country, the country is more unified, thus resulting in a positive effect on the development of a country. Economics suggests that the social justice be assessed with the GINI coefficient. It is used by the statistics institutions of the UN for analysis of individual income dynamics in a given country. That way one can see the situation with inequality of income. The main advantage of the coefficient usage is that it shows the inequality through ratio analysis, but not with overall figures like national income per capita or GDP per capita. The rise of the GINI coefficient together with GNP shows that the majority of the population remains poor.

Inequality influences negatively the overall social welfare. One of the indices that also measures inequality is the ratio of the population with income below the subsistence minimum. According to the Russian State Statistics Committee this ratio varies between the regions (Russian Federation - 11\%; Voronezh region - 9.1\%; Mary El republic - 19.5\%; Tyva republic - 35.1\%; Kalmyk republic - 35.4\% at 01.01.2014).

The average wage level is somehow a specific social indicator for Russia. It shows primarily provision of the subsistence minimum for the most low-qualified groups of the working population or even groups of people that have lost their specialization. Despite of some shortcomings the average wage level is the main welfare indicator because it can be easily interpreted.

Household savings represent a special economic phenomenon. They are a joint between individual and state interests. On the one hand savings is the most important standard of living indicator. Savings are closely connected to consumption, income and spending. On the other hand savings are a valuable resource for economic growth. It is the source of investments and crediting in an economy.

Keeping in mind all the above mentioned, the GINI coefficient, the average wage level in the country and the household savings are chosen to be the resulting indicators evaluating the social sphere of the country. Within the research this choice is stipulated by importance of these indicators not only for social sphere, but for economic development as a whole.

The methodology of the resource-oriented export strategy analysis is based on the assessment of interdependence of the fuel and energy sector (its oil segment) and the social sphere of the country. This methodological approach is chosen since it enables to examine the orientation of the export strategy of raw materials in Russia using the synergy of mathematical methods, information technology and economic knowledge. As a result of conceptual design, models were built according to social indicators and the resource-oriented export strategy thereby revealing the role of the individual structural units in the development of the fuel and energy sector. A priori we have studied the possibility of using such a methodological approach through a primary screening and in-depth study of the social sphere of the country. The expediency, the goal and promising applications of technologies are shown based on the synergy of mathematical methods, information technology and economic knowledge to minimize labor marginal costs and automate screening of various new indicators to analyze their dependence with the orientation of raw materials export strategy.

\section{Analysis and Discussion of the Methodology}

\subsection{Analysis of the Fuel and Energy Sector}

Russia is regarded as one of the leading energy producers in the world. The resource-oriented export strategy means that Russia is large oil and gas producer and exporter. The Russian economy is to high extent dependant on oil and gas exports.

Fuel and energy sector influences the perspectives of the national economics as a whole, providing about $1 / 4$ of GDP, $1 / 3$ of industrial production and the same share of consolidated budget receipts, about $1 / 2$ of federal budget receipts, exports and currency inflow. The economic growth is provided by the oil and gas exports, despite the high level of 
production and high market prices for these commodities. The share of Russia in the world production of oil and gas is constantly growing, now this share is about $12 \%$, which is on the second place in the world next to Saudi Arabia. However, the growth of oil production in Russia is on a downtrend.

The modern state of the Russian oil industry can be characterized with decreasing growth of oil reserves, lowering quality of the reserves, slowing down of their operation schedule; reduced number of exploration and production drilling, growing number of non-operated wells; overall transition to automatic oil extraction with severely reduced number of spraying wells; absence of substantial number of large oil fields; the need of industrial exploitation of the fields situated in remote regions; decreasing productivity of the sector.

The oil and gas industry is situated mainly within 5 oil and gas producing regions: Western Siberia (about $70 \%$ of all Russian oil production), Volga-Urals region (25\%), Timan-Pechora region (6\%), North Caucasian and Far East regions. The production of oil is distributed among the regions as following (at 2012, thsd. BPD): Western Siberia - 6,422; Urals-Volga - 2,312; Krasnoyarsk - 368; Sakhalin - 283; Komi Republic - 259; Arkhangelsk - 249; Irkutsk - 201; Yakutiya - 133; North Caucasus - 64; Kaliningrad - 26 [7].

Russia is the third oil producer in the world (after Saudi Arabia and the US). In May 2014 the average oil and liquid petroleum gas production according to the estimates [7] was $10.9 \mathrm{mln}$ BPD.

The Russian economy consumes less then $1 / 3$ of the produced oil (including the oil sub-products). During 2012 the production of oil and liquid petroleum gas in Russia according to the estimates was at average $10.4 \mathrm{mln}$. BPD (of which $9.9 \mathrm{mln}$. BPD is crude oil). About $3.2 \mathrm{BPD}$ is being consumed. The largest oil consumer is the US (consumption of 23 $\mathrm{mln}$. BPD, out of which only $8 \mathrm{mln}$. BPD is being produced, the rest is being imported).

The oil is being produced in Russia by more than 240 companies. 11 oil producing holdings (including Gazprom corp.) accounting for more than $90 \%$ of the production. The oil is mainly produced by vertically integrated companies, these companies are also the main oil exporters. Russia is the second largest oil exporter in the world out of the OPECcountries. Russia exported $7.2 \mathrm{mln}$. BPD in 2012 (Saudi Arabia - $8.9 \mathrm{mln}$. BPD), out of which about $5 \mathrm{mln}$. BPD was crude oil, the rest was oil sub-products. The main part of the Russian export goes to Europe (including the Eastern Europe), namely Germany, the Netherlands and Poland. About 18\% of the Russian oil export goes to Asian-Pacific region. More than $80 \%$ of the Russian oil is being exported through the Transneft system, the rest of oil is being transported with railways and ships.

The proved Russian oil reserves are $80 \mathrm{mln}$. barrels (at Jan. 2013, according to the experts of the "Neft i gas" journal. The majority of the Russian hydrocarbon resources are situated in Western Siberia, between the Urals and the Central Siberian Plateau and in the Volga-Urals region.

Russia possesses vast hydrocarbon resources in the North Shelf and the Arctic shore. The resources of only one Russian Arctic Shelf are assessed of 100 bln. th. of oil equivalent, so its exploitation can be a long one. However, the development of the northern shelf fields and the Arctic shore fields is closely connected with various geo-economic risks including severe climate conditions. According to Russian law the northern shelf fields can be developed only by the companies with governmental control and with at least five years of experience of shelf field development. These conditions are valid since 2008.

The most of oil is still being produced in Western Siberia, namely in Priobsk and Samotlor fields. The Russian companies expand their activity in the Arctic and in Eastern Siberia, using tax exemptions and lowered oil export tariffs. In the long run together with undeveloped oil reserves of the Eastern Siberia and the Russian Arctic, Sakhalin may also play an important role.

\subsection{Analysis of the Social Sector}

The model of dependence of the social sphere on the fuel and energy sector has been molded in Russia. Compared to the economic growth, stipulated by the resource-oriented export strategy, the social sphere of the Russian economy is not very promising.

The analysis of the selected indicators of the social sphere has detected the following problems.

The GINI coefficient for Russia is constantly growing since 1990 (24) with a minor decrease in 1995 (38.7). So that in 2012 it increased to 42.

The GINI coefficient was obtained with Rosstat statistics where the unofficially paid wages are not considered. One can assume, that the Russian GINI coefficient is very close to that of Brazil (57) or even exceeds it because the real income of the upper-class minority is very high if compared to the income of the low-paid majority.

The average wage level and the household savings for the period 1990-2012 has an upward trend, i.e. the average wage level in 1990 was $\$ 409.22$ per month, in 2012 it was already $\$ 802.00$ per month; the household savings 
were $\$ 117$ bln. in 1994, in 2010 it was $\$ 409$ bln. However the growth rate of the household savings is higher than the growth rate of the average wage level. Sufficiently high growth of the household savings may be a sign of favorable economic situation in the country. However, the growing difference of the wages between various types of economic activities increases inequality in Russia. According to the Ministry of economic development the wage-level leaders are the sectors of finance and fuel and energy. The average monthly wage in these sectors is 2.1-2.3 times higher than the average wage level as a whole. The outsiders in the wage-level list are textile and clothing manufacturing ( $44 \%$ of the average wage level), leather manufacturing and shoe manufacturing (49\%) and agriculture (51\%).

\subsection{Model of the Interdependence of the Oil Sector and Social Sector}

\subsubsection{Selection of the Model}

Choosing the type of the production model was based primarily on the results of the preliminary content analysis, according to the theoretical assumptions about the nature of the development process being studied, i.e. impact of production, export and prices of oil on selected indicators that assess the social sphere. Analysis of the relationship between social development indicators and natural resources is estimated by the following model of the form:

$$
y=A D^{B} E x^{C} e^{\sigma p}(1)
$$

where $y$ - resulting indicator; $D$ - extraction of oil; Ex - export of oil; $P$ - price of oil.

This model is a power function. Therefore for simplicity, the equation has been transformed to obtain a linear equation. The transformed equation is as follows:

$\ln y=\ln A+B \ln D+C \ln E x+(\sigma p)$

An important component of the econometric model is the selection of factors that significantly affect the studied parameters. Thus these factors are included in the model being developed. Optimal set of factors was determined on the basis of qualitative and quantitative analysis. All factors have been included in the model whose impact should be taken into account when considering impact of energy resources on the social development, i.e. production, exports and the price of oil. In the next steps feasibility of incorporating of each factor into the model has been tested with the help of formal statistical methods.

First, the factors have been examined based on correlation between them. A high correlation between the factors results in unreliable estimates of the model parameters due to multicollinearity issues. In order to estimate single impacts of the indicators one or more factors have been omitted. Of the two correlated factors the one which is more correlated with the other has been excluded.

Criteria for including factors in the model are the degree of their isolated influence on the resulting indicator, defined by the coefficient of correlation. The method of ordinary least squares has been used to estimate the coefficients.

Closeness of the relationship of the studied phenomena has been assessed with the coefficient of determination $R^{2}$. At each step the regression model was constructed and the significance of factors was tested. The analysis shows that the residuals tend to a normal distribution. To test the significance of the factors Student's $t$ test and Fisher criterion have been used. Assessment of the quality of the constructed model was also carried out by using Durbin-Watson statistics, showing the presence of autocorrelation in the residuals.

\subsubsection{Empirical Specification and Regression Results}

Frist the relationship between GINI index and production, exports and prices of oil is discussed. Data in Table. 1 shows that the Gini coefficient increased in the past twenty years. During the same period Russia's GDP also grew. But if the Gini coefficient increases with GDP, the majority of the population remains poor. In the same period of time oil production and exports also tended to increase. One can also see upward price trends except in 2009.

In accordance with the methods of the analysis model (1) was transformed by taking the logarithm:

$\ln G I N I=B \ln D+C \ln E x+(\sigma p)$

The correlation analysis shows that the strongest relationship is between GINI index and exports of oil (0.59), then between $\mathrm{GINI}$ index and the price of oil (0.3). Finally the relationship between $\mathrm{GINI}$ index and production of oil is negative $(-0.1)$.

The regression results show that $\mathrm{R}^{2}$ is 0.95 . Calculated value of Fisher coefficient is greater than the critical level, suggesting the importance of the equation in total. All coefficients of the model are statistically significant. The equation is:

$$
\ln G I N I=6,25-0,89 \ln D+0,51 \ln E x+(0,00036 p)(4)
$$


We can say that an increase in the exports and the price of oil is associated with an increase in the GINI coefficient. However and increase in production of oil is associated with a decrease in the GINI coefficient.

The relationship between the average wage and production, exports and prices of oil shows the following pattern. Table 1 indicates that there are two specific periods of time, with different trends in average wages in Russia: between 1992 and 1998 and between 1999 and 2012. The first period is characterized by high volatility and the second by an increasing trend.

Table 1: Production, exports and the price of oil, GINI coefficient, average wage, savings, 1990-2012

\begin{tabular}{|c|c|c|c|c|c|c|}
\hline Year & Production & Exports in & Price & GINI & Wage & savings \\
\hline 1990 & 516 & 109 & 304 & 24,0 & 409,22 & na \\
\hline 1991 & 462 & 117 & 255 & 26,0 & 101,36 & na \\
\hline 1992 & 399 & 128 & 236 & 29,0 & 23,96 & na \\
\hline 1993 & 354 & 127 & 199 & 40,0 & 140,67 & na \\
\hline 1994 & 318 & 126 & 182 & 41,0 & 66,85 & 116,85 \\
\hline 1995 & 307 & 122 & 189 & 38,7 & 130,38 & 110,83 \\
\hline 1996 & 301 & 121 & 224 & 38,7 & 181,39 & 103,90 \\
\hline 1997 & 306 & 123 & 200 & 39,0 & 176,58 & 88,86 \\
\hline 1998 & 303 & 137 & 126 & 39,4 & 80,22 & 46,49 \\
\hline 1999 & 305 & 134 & 170 & 40,0 & 73,69 & 55,33 \\
\hline 2000 & 324 & 144 & 273 & 39,5 & 82,33 & 93,90 \\
\hline 2001 & 348 & 165 & 223 & 39,7 & 115,00 & 101,11 \\
\hline 2002 & 380 & 190 & 218 & 39,7 & 139,00 & 99,10 \\
\hline 2003 & 421 & 228 & 259 & 40,3 & 179,00 & 125,15 \\
\hline 2004 & 459 & 260 & 342 & 40,9 & 234,00 & 182,33 \\
\hline 2005 & 470 & 253 & 440 & 40,9 & 297,00 & 237,95 \\
\hline 2006 & 481 & 248 & 497 & 41,5 & 404,00 & 304,45 \\
\hline 2007 & 491 & 259 & 531 & 42,2 & 529,00 & 391,91 \\
\hline 2008 & 488 & 243 & 728 & 42,1 & 691,00 & 539,38 \\
\hline 2009 & 494 & 248 & 428 & 42,1 & 658,00 & 281,57 \\
\hline 2010 & 495 & 251 & 561 & 42,1 & 711,41 & 409,15 \\
\hline 2011 & 508 & 245 & 665 & 41,7 & 797,00 & na \\
\hline 2012 & 518 & 240 & 699 & 42,0 & 802,00 & na \\
\hline
\end{tabular}

Table 1: Production, exports and the price of oil, GINI coefficient, average wage, savings, 1990-2012. The production of oil is measured in millions of tons, exports of oil are measured in millions of tons, price of oil is measured in US dollars per ton, wage is measured in US dollars, savings are measured in billions of US dollars. Source: UIMISS (2015)

The following regression has been estimated:

$W=A D^{B} E x^{C} e^{\sigma p}$

where W - wage; D - extraction of oil; Ex - export of oil; P - price of oil.

The correlation coefficients between variables used in the model above show the following. The strongest correlation is between wage and the price of oil $(0.84)$. The correlation between the production of oil and wage is 0.73 . The weakest correlation is between exports and wage (0.7). The equation is as follows:

$\ln W=-1,4+0,64 \ln D+0,32 \ln E x+(0,0033 p)(6)$

The regression analysis shows that $\mathrm{R}^{2}$ is 0.85 . Calculated value of the Fisher coefficient is greater than the critical level, suggesting the importance of the equation in total. But significant is only one indicator - the price.

This could be because of the multicollinearity issues caused by the high correlation between the explanatory variables. In order to be able to assess the single effect of the indicators we exclude the insignificant indicators from the regression equation leaving a model with two explanatory variables. In the changed models two indicators remain insignificant. Thus we exclude again one of the explanatory variables. Therefore a model with price of oil as a single explanatory remains for the analysis. The equation is as follows:

$W=e^{3,82+0,0044 p}$

The results of the regression with two explanatory variables show that $\mathrm{R}^{2}$ is equal to 0.84 . Calculated value of the Fisher coefficient is greater than the critical level, indicating the importance of the equation in total. Price is a statistically significant indicator. We can say that the growth of oil prices is associated with an increase in wages. 
To analyze the relationship between savings and production, exports and prices of oil the following regression has been estimated:

$$
S=A D^{B} E x^{C} e^{\sigma p}
$$

where S - savings; D - extraction of oil; Ex - export of oil; P - price of oil.

The correlation analysis shows that the correlation between savings and the price of oil is 0.896 , between the savings and production of oil is 0.89 and between savings and exports of oil is 0.8 .

Results of the regression analysis show that $\mathrm{R}^{2}$ is 0.98 . Calculated value of the Fisher coefficient is greater than the critical level, suggesting the importance of the equation in total. All coefficients of the model are statistically significant. Equation is as follows:

$\ln S=-17.7+0,64 \ln D-3,11 \ln E x+(0,0017 p) \quad(9)$

An increase in production and price of oil is associated with an increase in savings. An increase in exports however is associated with a decrease in savings.

\section{Is the Resource Oriented Russian Exporting Strategy Still Valid?}

The suggested methodological approach for testing the validity of the existing Russian export strategy is built on the assessment of interaction of the oil and social sectors.

The research has shown that increasing oil production and rising oil price lead to increased household savings, whereas rising oil exports decrease savings. The GINI coefficient rises with rising oil exports and rising oil prices, and it goes down with increased oil production. Rising oil price push wages even higher. Although exports of natural resources have a negative impact on household savings, an increase in consumption of energy resources makes development of the social sector possible.

Hence, the resource-oriented export strategy provides the economic growth in Russia. The resource-oriented export strategy is capable of developing the social sphere of the country provided the further growth of energy resources consumption is on an increasing trend.

The fulfilled analysis indicates that he resource-oriented export strategy still remains valid at least on this stage of economic development. However, further increases of oil exports together with reduction or even insufficient growth of domestic consumption of the energy resources may have a negative impact on the social sphere.

In order to estimate the existing Russian export strategy in the long run some deeper research is needed. Further research should consider primarily the factors influencing consumption of energy resources. One should also examine the production possibility curve in $\mathrm{n}$-dimensional space in order to assess the strategy and the redistribution of resources in favor of the resource sector in comparison to other sectors.

\section{Conclusion}

The article presents the methodology for assessing the resource-oriented Russian export strategy. The success of the strategy was measured through its impact on the social sphere and thus on the human being.

The results suggest that the existing export strategy has already become obsolete. This statement has been tested in several steps. The fuel and energy sector has been assessed with the following indicators: oil production in Russia and Russian oil exports. The place of the oil sector as the major element of the fuel and energy sector has been shown. The social sphere has been characterized with the following indicators: GINI coefficient, average wage level and household savings. The dynamic analysis was accomplished based on the data for the years 1990-2012. A power production function has been utilized for the analysis of the resource-oriented export strategy of the Russian economy.

Three multiple regression equations were obtained through taking a logarithm of the production function. These three equations represent the models of the economic process for the GINI coefficient, for the average wage level and national savings. For estimation of the coefficients in the regression equations the ordinary least squares method was used. The significance of the relationship between the export flows and social sector indicators has been assessed with $\mathrm{R}^{2}$. The quality estimation of the obtained regression coefficients is made with t-statistics. The quality of the composed model was assessed with the help of Durbin-Watson statistic that reflects the presence of autocorrelation in the residuals. The statistic is within [0;4]. After accomplishing the econometric analysis implications have been made about the significance of the oil production, oil export and the oil price for the social sphere. The analysis of the model has shown that increasing oil production and rising oil price lead to increased household savings, whereas rising oil exports decreases savings. The GINI coefficient rises with rising oil exports and rising oil prices, and it decreases with oil production. Rising oil price push wages even higher. 
It follows from the obtained results that the exports of natural resources have a negative impact on household savings. However an increase in consumption of energy resources makes development of the social sector possible.

The accomplished testing of the export strategy has shown that the existing resource-oriented Russian export strategy is still effective. The current export strategy is capable of maintaining the social sphere provided the further growth of energy resources consumption is on an increasing trend. Hence, the country with rich resources should follow the policy of restricting resource exports and stimulating resource for domestic consumption.

\section{Acknowledgement}

The article is based on the materials of the Project №14-38-00009 "The program-targeted management of the Russian Arctic zone development" of the Russian Science Foundation. Peter the Great St.Petersburg Polytechnic University.

\section{References}

Balassa B. (1978). Exports and economic growth: further evidence. J Devel Econ 5, P. 181-189.

Corden, W. M. (1984) Booming Sector and Dutch Disease Economics: Survey and Consolidation. Oxford Economic Papers. Vol. 36.

Didenko N. (2007). International Economics, Feniks: Rostov on/Don, pp.45-49.

Didenko N. and Skripnuk D. (2014) The impact of energy resources on social development in Russia" WIT Transactions on Ecology and the Environment, Vol 190,WIT Press.

Edwards, S. and M. Aoki (1983). Oil Export Boom and Dutch-Disease: A Dynamic Analysis. Resources and Energy.

Energy Information Administration (EIA). http://www.eia.gov. (Mai 15, 2015)

Giles J. A., and Williams C. L. (2000a). Export-led Growth: A Survey of the Empirical Literature and Some Non-causality Results. Part 1. Journal of International Trade and Economic Development., 9(3). P. 261-337.

Giles J. A., and Williams C. (2000b) L. Export-led Growth: A Survey of the Empirical Literature and Some Non-causality Results. Part 2. Journal of International Trade and Economic Development. 9(4). P. 445-470.

Gouriev S. and Sonin K. (2008). The economy of the "resource curse". Voprosy Eknomiki. Vol. (4).

Hutchison, M. M. (1994). Manufacturing Sector Resiliency to Energy Booms: Empirical Evidence from Norway, the Netherlands, and the United Kingdom. Oxford Economic Papers New Series. Vol. 46(2).

Kimelman S.A., and Andriushin S.A. (2007) The resource component of the Russian regional economics. Voprosy Eknomiki. Vol. 6.

Lederman D., Olarreaga, and M., Payton, L. (2010). Export promotion agencies: do they work? Journal of Development Economics.

Lederman D., Olarreaga, M., Payton, L. (2007). Export Promotion Agencies: What Works and What Doesn't? World Bank Working Paper.

Leonidou L. (1995). Export Stimulation Research: Review, Evaluation and Integration, International Business Review.

Martincus C., A. Estevadeordal, A. Gallo, J. Luna. (2010). Information Barriers, Export Promotion Institutions, and the Extensive Margin of Trade. IDB Publications from Inter-American Development Bank No 39358.

The Unified Inter-ministerial Information and Statistics System (UIMISS). http://www.fedstat.ru. (Mai 15, 2015) 
ISSN 2039-2117 (online)

ISSN 2039-9340 (print)
Mediterranean Journal of Social Sciences MCSER Publishing, Rome-Italy
Vol 6 No 5 S2

September 2015 